\title{
High Risk Fungicides Combined to Low Risk Can Be a New Strategy for Management of Asian Soybean Rust at the Beginning of the Epidemic
}

\author{
Roberto B. O. Ponce ${ }^{1}$, Laércio Zambolim ${ }^{1}$, Antonio A. Fortunato ${ }^{1}$ \& Luan F.de Queiroz ${ }^{1}$ \\ ${ }^{1}$ Laboratório Proteção de Plantas, Departamento de Fitopatologia, Universidade Federal de Viçosa, Viçosa, \\ Minas Gerais, Brazil \\ Correspondence: Laércio Zambolim, Laboratório Proteção de Plantas, Departamento de Fitopatologia, \\ Universidade Federal de Viçosa, Viçosa, Minas Gerais, Brazil. E-mail address: Zambolim@ufv.br
}

Received: September 5, 2018

Accepted: October 16, $2018 \quad$ Online Published: December 15, 2018

doi:10.5539/jas.v11n1p149

URL: https://doi.org/10.5539/jas.v11n1p149

The research is financed by Conselho Nacional de Pesquisas (CNPq); Fundação de Amparo a Pesquisa do Estado de Minas Gerais (FAPEMIG).

\begin{abstract}
Asian soybean rust (ASR) caused by Phakopsora pachyrhizi since it was first reported in Brazil in 2001 has been subject of studies regarding the use of fungicides to its control. Low efficiency of triazol (demethylator inhibitors-DMI's) or stobilurin (quinone outside inhibitor-QoI's) has been reported on the control of ASR under field conditons. For this reason experiments were conducted to study the effects of these systemic fungicides associate with protectant multi-site fungicides (MSF) on ASR control preventively and at the onset of the epidemic. All combinations of fungicides were effective to control ASR and promoted greater soybean yield gain compared to the control. The analysis of the efficacy of ASR control in the lower, medium and upper part of the plant canopy, showed that application of Epoxiconazole + Pyraclostrobin and Cyproconazole + Azoxystrobin reduced ASR and leaf fall (\%), and increased soybean yield grain. The severity of the disease increased from the lower to the upper part of the plant. The application of DMI+ QoI associated with MSF applyed when disease severity reached $2 \%$, promoted effective reduction of ASR, increased yield and reduced leaf fall. Overal the DMI's + QoI's associated with MSF was 68\% and 70.2\% more efficient on ASR control and soybean grain yield, respectively than the control. Mancozeb and Chlorothalonil associated with the lowest dose of Epoxiconazol + Pyraclostrobin (10.2 + 33.2 g.a.i./ha) or Cyproconazole + Azoxystrobin (12.5 + 30.0 g.a.i./ha), respectively increased soybean grain yield at least 45.0\%; the same combinations of the fungicides Epoxiconazol + Pyraclostrobin (15.3 + 49.8 g.a.i./ha) and Cyproconazole + Azoxystrobin $(25.0+60.0$ g.a.i./ha) 50\% less than the commercial dose, increased $89.5 \%$ and $109.0 \%$, respectively. The use of high risk (DMI and QoI) fungicides combined to low risk (MSF) applyied properly, can be a new strategy for the management of ASR at short and long term, even after the epidemics has reached 2.0\% severity. Furthermore, due to the residual effect, MSF can promote higher longevity of DMI and QoI molecules.
\end{abstract}

Keywords: Phakopsora pachyrhizi, DMI, QoI, protectant fungicide

\section{Introduction}

Among all diseases affecting soybean, Asian soybean rust (ASR) caused by the fungus Phakopsora pachyrhizi (Syd. and P. Syd.) can be considered nowadays in Brazil as the main threat of the crop production (Godoy et al., 2015; Godoy et al., 2016). In the absence of control measures, yield losses of up to $90 \%$ have been reported in north America (Bromfield, 1984; Hartman et al., 2015). The fungi is considered highly aggressive, causing damages varying from 10 to $90 \%$ in soybean fields in Asian (Sinclair \& Hartman, 1999) and yield losses ranging from 10 to $80 \%$ in some growing regions in South America (Navarini et al., 2007). The first symptoms of ASR begin as very small brown or brick-red spots on leaves, grouped into tanned coloring lesions (2-5 $\mathrm{mm}$ in diameter) then develop into a pustule (uredinia) where an abundant sporulation produced, help the fungus dissemination (Bromfield, 1984). In the field, these spots usually begin in the lower canopy at or after flowering, 
and often the first lesions appear toward the base of the leaflet near to the petiole and leaf veins (Sinclair \& Hartman, 1999).

The fungus presents a short life cycle, which means under optimal conditions (frequent rain events, long dew periods and temperatures ranging from 15 to $29{ }^{\circ} \mathrm{C}$ ), ASR epidemics can quickly build up from almost undetectable levels to very high levels, and the urediniospore production can reach for at least three weeks (Dorrance et al., 2005; Melching et al., 1989). Rapid disease development has been correlated with canopy closure and bloom stage (R1+) (Dorrance et al., 2005; Fehr et al., 1981; Koch et al., 1983). Then ASR progresses until complete canopy defoliation, or until the environment is no longer conducive for disease development (Sinclair \& Hartman, 1999). According to Bromfield (1984), the infection at flowering can produce high levels of damage, compromising pod formation and filling, final grain weight (Yang et al., 1991), and also affecting the protein content (Ogle et al., 1979).

Since ASR first report in Brazil, the chemical control of this desease was based on fungicides belonging to triazoles or "demethylation inhibitors" (DMI) group (Yorinori \& Lazzarotto, 2004). These fungicides inhibit the sterol C-14 $\alpha$-demethylation of 2,4-methylenedihydrolanosterol, a precursor of the cell membrane component ergosterol in fungi (Brent, 1995). The DMI group is classified as single-site fungicide and is associated to be a high risk factor in the development of resistance in fungi population (FRAC, 2015). Consequently, associated to the massive use of this chemical group for many years in soybean fields, resulted of the selection of resistant strains of $P$. pachyrhizi from the fungus population, and consequently loss in control efficacy of DMIs. In 2005/06 soybean season, ASR average control by DMIs was $90.3 \%$, whereas in 2012/13, DMI control was 52.0 (42\% reduction in the control efficacy) (Godoy et al., 2013). After 2005 the "quinone outside inhibitors" (QoIs) were also used to control the disease (P. J. M. Andrade \& D. F. A. A. Andrade, 2006). The QoI fungicides are very effective against a broad spectrum of fungi and inhibity mitochondrial respiration, effectively stopping energy production of the fungus, and result in cell death. But QoI fungicides also have a very specific site of action for this reason the risk of resistance development is high. Currently there are more than 20 plant pathogens with some level of resistance to QoI fungicides as well as P. pachyrhizi (FRAC, 2015).

In the last years, new fungicides belonging to carboxamide group, a single-site molecule that acts inhibiting the complex II, of the respiration process inside the fungal cell has been developed to control ASR. However resistance to other pathogens, had already been documented for this new group (FRAC, 2015). Fungicides with single-site action mode are at relatively high risk for resistance development compared to those with multi-side action mode. Most fungicides being developed today have a single-site mode of action because this is associated with lower potential for negative impact on the environment, including non-target organisms (McGrath, 2004). It is well known that MSF's affect multiple target sites, interfering with numerous metabolic processes of the fungus, and consequently fungicide resistance is rare with this type of chemicals (Zambolim et al., 2007).

The high fungal adaptability in soybean fields make difficult to control of ASR with fungicides as reported above that is becoming increasingly evident (Blum, 2009; Schmitz et al., 2014). Due to the high risk fungicide resistance (DMIs or QoIs) and the succinate dehydrogenase inhibitor (SDHI) applied alone or in mixture, it will be necessary to find broad spectrum fungicide action to be incorporated in an integrated ASR control. In the present research it was also evaluated the preventive and curative (when the disease reached $2.0 \%$ severity) control of ASR. For these reasons, this study evaluated triazol associated with strobilurin combined with multi-site broad spectrum fungicides on the control of ASR.

\section{Material and Methods}

\subsection{General Procedures}

All the experiments used soybean of the cv. "Monarca" (Plant breeding laboratory Universidade Federal de Viçosa). The inoculum of P. pachyrhizi (Plant protection laboratory, Universidade Federal de Viçosa) with a minimum of $90 \%$ germination was produced under greenhouse conditions (temperature $25 \pm 2{ }^{\circ} \mathrm{C}$ day and $20 \pm 2$ ${ }^{\circ} \mathrm{C}$ night; relative humidity $80 \pm 3 \%$ ).

The experiments were conducted at the research field station at the Universidade Federal de Viçosa, in Viçosa, Minas Gerais state $\left(20^{\circ} 45^{\prime} 14^{\prime \prime} \mathrm{S} 42^{\circ} 52^{\prime} 55^{\prime \prime} ; 648 \mathrm{~m}\right.$ high) in the growing season 2016/2017. Soybean seeds were sown in the experimental area in a soil with no cultivation till system, in four rows of $5 \mathrm{~m}$ each, spaced $0.5 \mathrm{~m}$ apart (300,000 plants/ha) per plot. Only the two of the four central rows were used for data collection.

Cropping practices were performed according to the extension instructions for soybean crop. The fertilization was done using the commercial formula 05-25-20 (Nitrogen-Phosphorus-Potassium) at $250 \mathrm{~kg} / \mathrm{ha}$. Nutrient 
soybean foliar analyses was done at the R1 stage (beginning flowering) of the field trials. All experiments were inoculated with a urediniospores suspension $\left(10^{8}\right.$ uredospores $\left./ \mathrm{mL}\right)$ of $P$. pachyrhizi.

Trial 1 was performed in an area previously cultivated with crucifers for two years, trial 2 with potato for two years, and trial 3 with maize for two years, respectively. Urediniospores suspension $(100 \mathrm{~mL})$ was sprayed in the plant canopy at night, of soybean rows using a manual backpack mistblower, 25 days before the application of the fungicides. The fungicides spraying was performed at different plant growth stages R1(beginning flowering), R2 (full flowering), and R5 (beginning seed) using a manual backpack sprayer (Jacto PJH, JD-12P spray nozzle) calibrated to apply a spray volume of $150 \mathrm{~L} / \mathrm{ha}$, on the adaxial surface of the expanded leaves of each plant of the two center soybean rows.

Three trials were conducted to study the effect of triazol associated with strobilurin combined with MSFs on the control of ASR at the beginning of the epidemic (Table 1). In the trial 1, the purpose was to study the preventive effect of the fungicides (before the first symptoms) and, trials 2 and 3 curative effect on the control of ASR, on the lower part of soybean plants at the two center rows (disease severity at 2.0\%) (Godoy et al., 2006). The fungicides were applied based on the $\mathrm{g}$ of a.i./ha. The fungicides and field doses recommended by the commercial supplier were: Dithane M 45 PM 3.0 Kg/ha; Daconil 500 PM, 3.0 Kg/ha; Opera SC 0.6 L/ha; Priori-Xtra SC 0.3 L/ha; Polyram DF $3.0 \mathrm{Kg} / \mathrm{ha}$.

Table 1. Treatments used in the three trials to study the effect of triazol + strobilurin + multi-site fungicides on the control of Asian soybean rust

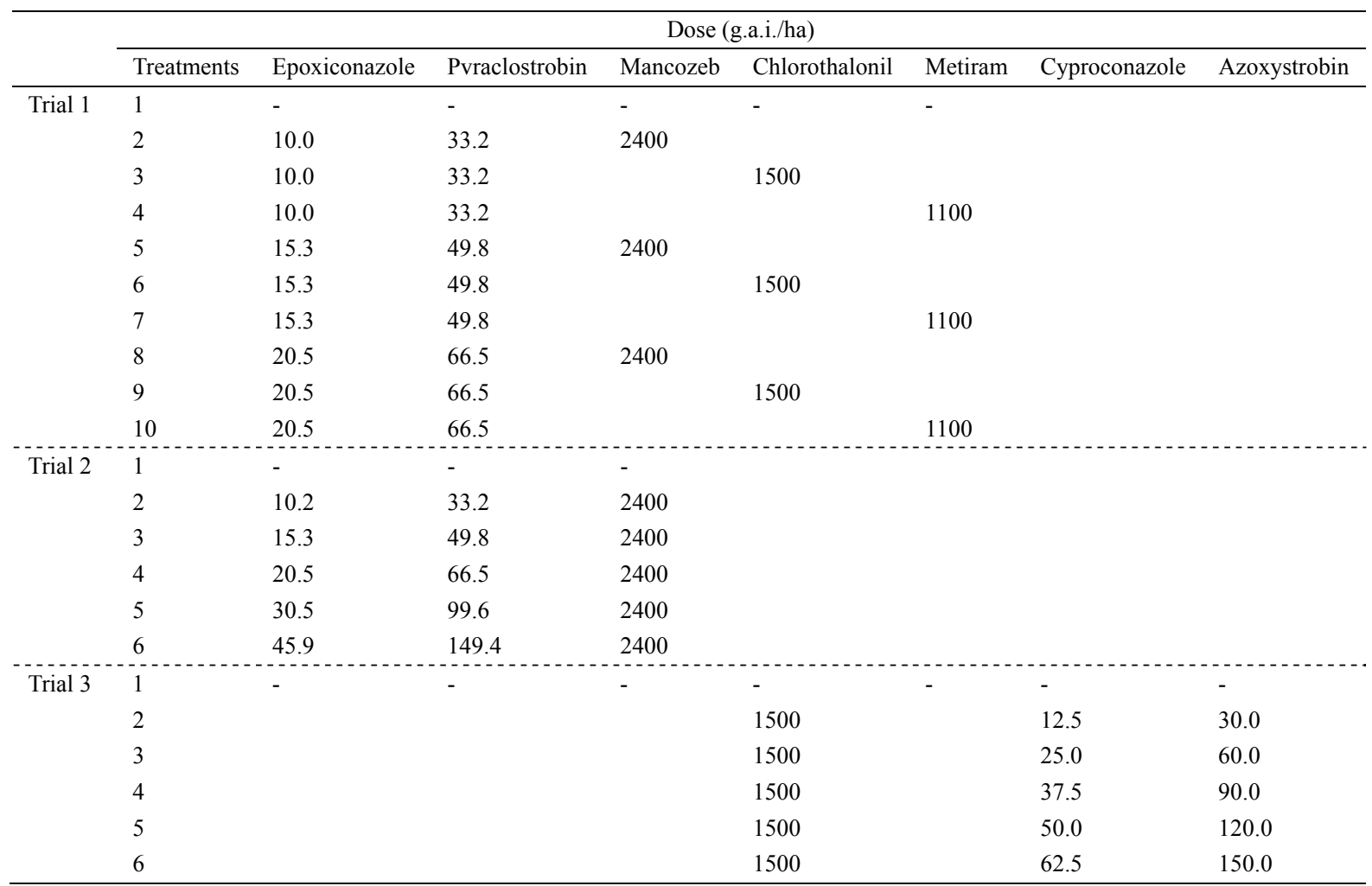

Three soybean plants of each replication was randomly removed at weekly interval at R1 (beginning flowering) to R7 (beginning maturity) stages (Fehr et al., 1981) to evaluate the severity of the disease. Data was taken from the lower, medium and upper part of the canopy evaluating all the leaves of the plants in the replication. The severity of the disease was performed by counting the number of sporulated lesions with uredia and uredosporos in ten randomly areas $\left(1 \mathrm{~cm}^{2}\right)$ of each leaf under a stereoscopic microscope (Carl Zeiss Axio Imager A1, Gottingen, Germany) at $20 \times$.

Field assessment of defoliation was done before harvesting, for each replication using an arbitrary scale ranging from 0 to $100 \%$. The evaluation occurred on the R8 (Full maturity) stage by the time that the control treatment had 85 to $90 \%$ of leaf fall. 
Trials were setup in a randomized complete block design with ten (trial 1) and six (trial 2 and 3) treatments, respectively with four replications.

\subsection{Yield Determination}

Soybean grain yield was harvested at R8 stage. Harvest was manually performed and grains were threshed in a stationary threshing machine, cleaned, weighed. The results were corrected to $13 \%$ humidity.

\subsection{Experimental Design and Data Analysis}

With severity data of the different evaluations, the area under the disease progress curve (AUDPC) was calculated by the trapezoidal integralization method (Shanner \& Finley, 1977; Kranz \& Rotem, 1988).

Data from all variables were analyzed by analysis of variance (ANOVA) and means from the treatments were compared using Tukey test $(P \leq 0.05)$ using SAS (version 6.12; SAS Institute, Inc., Cary, NC).

\section{Results}

Results from one of the two representative trials (1,2 and 3) developed in the field conditions are shown. The environmental conditions favored the severity of ASR (data not shown). Due to the previously inoculation of the plants the severity of the disease was very high in all the experiments. The results of the effect of doses of Epoxiconazle + Pyraclostrobin associated with multi-site fungicides (Mancozeb, Chlorothalonil and Metiram) to control ASR and on grain yield (trial 1) are presented in Figures 1 and 2, respectively. On the trial 1, the fungicides were sprayed before the symptoms of the disease on the leaves, whereas on trials 2 and 3 they were applied after the disease reached $2.0 \%$ severity (curative effect). The severity of the treatments (fungicides) did not differ on ASR control regarding the position of the disease on the plant canopy lower, medium and upper. However, the disease from lower to upper part in all fungicidal treatments were significantly lower compared to the control treatment. The AUDPC decreased from the lower to upper part of the plant canopy (Figure 1). Leaf fall was $90.6 \%$ on the control treatment and from $43.3 \%$ to $50.3 \%$ for the best treatments (from 3 to 10 ). The treatments that differed significantly from the control, as far as soybean yield is concerned, were treatments 9 and 10. (Figure 2). Although the fungicidal treatments did not differed between them, the best treatment 3 yielded $34.0 \%$ over treatment 10 (Figure 2). Yield increased from 25.3 (treatment 10) to $91.5 \%$ (treatment 3) Figure 2.

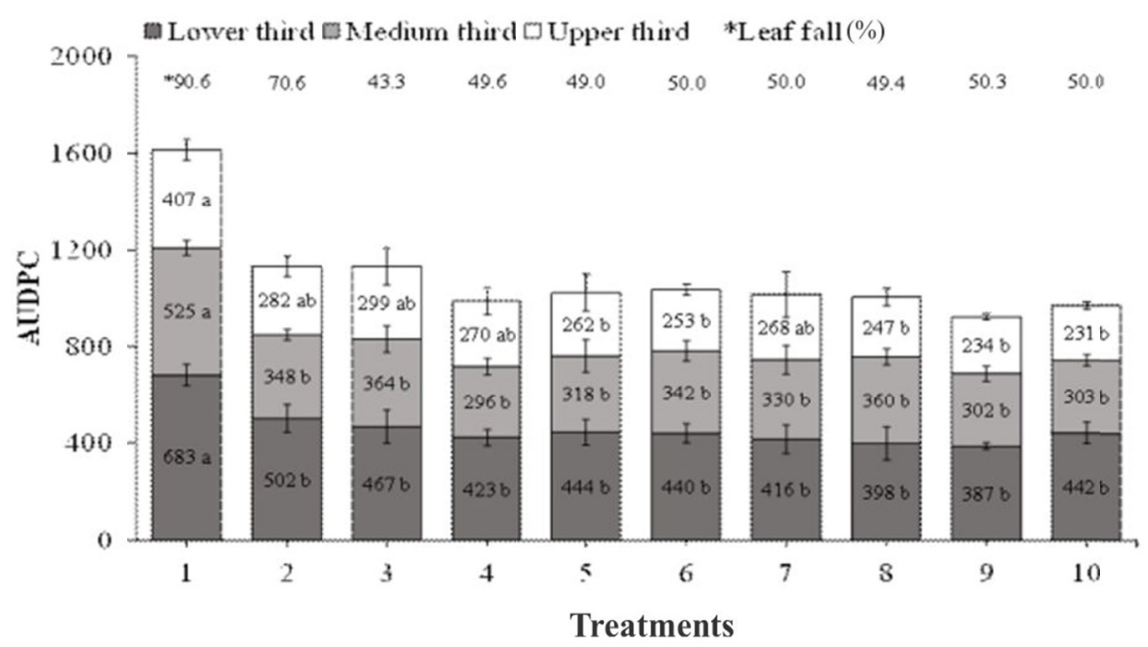

Figure. 1. Effect of doses of Epoxiconazole + Pyraclostrobin mixtured with multi-site fungicides on the AUDPC (ASR) (Trial 1). The bars represent the standard error of the means $(n=3)$. Results from one of the two representative experiments are shown. AUDPC: area under disease progress curve; * leaf fall (\%). 


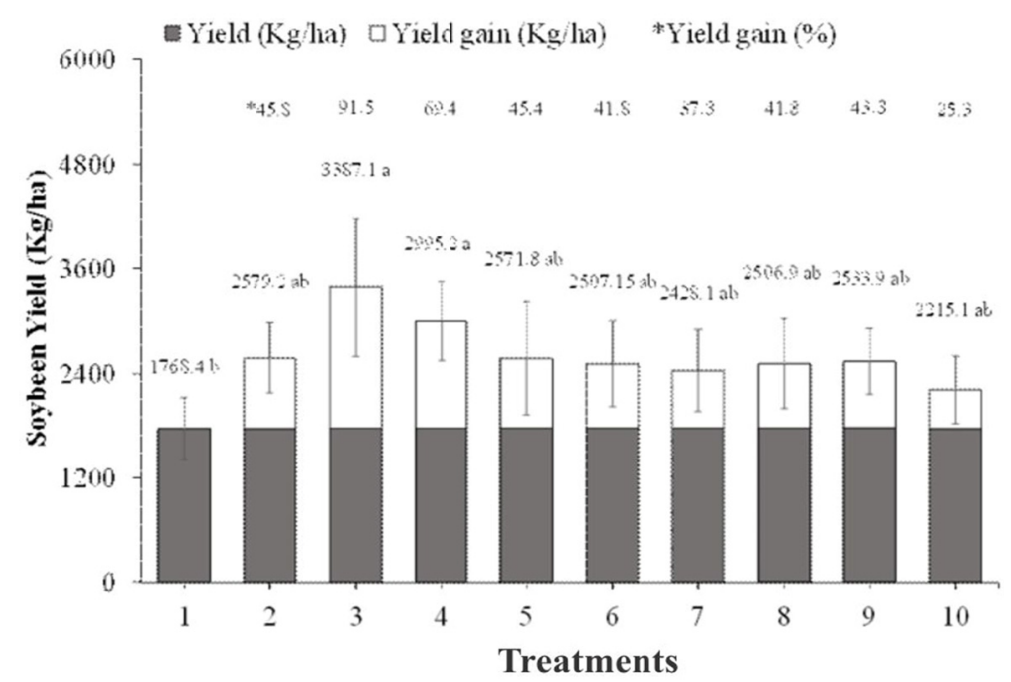

Figure 2. Effect of doses Epoxiconazole + Pyraclostrobin mixtured with multi-site fungicides, on soybean grain yield (Trial 1). The bars represent the standard errors of the means $(n=3)$. Results from one of the two representative experiments are shown. * Yield gain was obtained in relation to the control treatment

The curative effect of Epoxiconazole + Pyraclostrobin associated with Mancozeb on ASR control and on grain yield (trial 2), are shown in Figures 3 and 4, respectively. Except for the control, in almost all the treatments the severity of ASR did no vary between lower, medium and upper part of the plant canopy. All the fungicidal treatments differed from the control but they did not differ between them (Figure 3). Considering leaf defoliation, except the treatment 2 with $72 \%$ defoliation, all the other fungicidal treatments ( 3 to 10 ) varied from 32.5 to $34.5 \%$. The control (treatment 1 ) presented $90 \%$ of leaf fall.

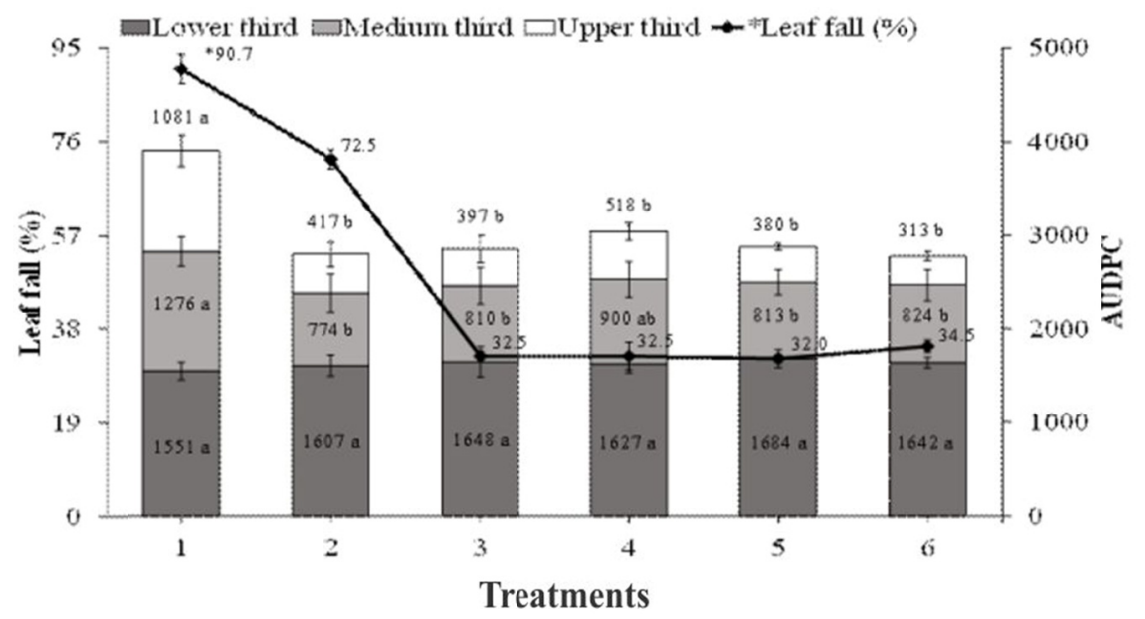

Figure 3. Curative effect of doses of Epoxiconazole + Pyraclostrobin mixtured with Mancozeb on the AUDPC (ASR) and leaf fall (Trial 2). Results from one of the two representative experiments are shown.

AUDPC: area under disease progress curve 


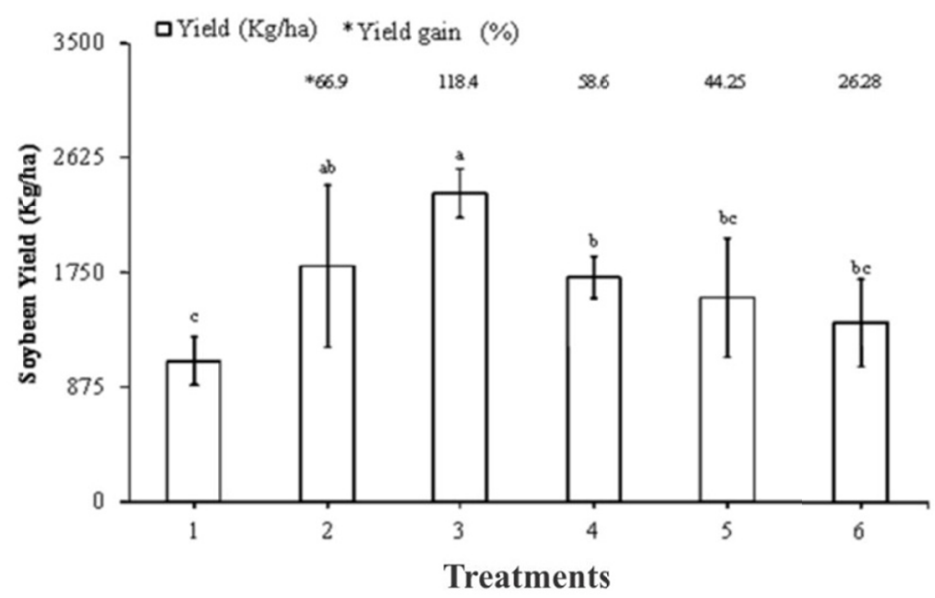

Figure 4. Curative effect of dose rate of Epoxiconazole + Pyraclostrobin mixtured with Mancozeb on soybean grain yield (Trial 2). Means followed by the same letter do not differ by the Tukey test $(P \leq 0.05)$. The bars represent the standard errors of the means. Results from one of the two representative experiments are shown

The curative effect of dose rate of Epoxiconazole with Pyraclostrobin associated with Mancozeb on soybean grain yield is on the Figure 4. Except the treatments 2, 5 and 8, all the other treatments differed from the control.

The results of the effect of doses of Cyproconazole + Azoxystrobin associated with the Chlorothalonil on ASR control (AUDPC), leaf fall and soybean yield are shown in Figures 5 and 6, respectively. Except for the control (treatment 1 ) in all the treatments (2 to 6), the severity of ASR varied between lower, medium and upper part of the plant canopy (Figure 5). The severity of ASR for all the treatments (3 to 6) except treatment 2 differed from the control (Figure 5). Leaf defoliation for the control was $85.2 \%$ whereas for the other treatments varied from 38.2 to 45.7. All the treatments differed from the control in grain soybean yield, except treatment 6 (Figure 6). Yield gain varied from 55.7 (treatment 6 ) to $109.0 \%$ (treatment 4).

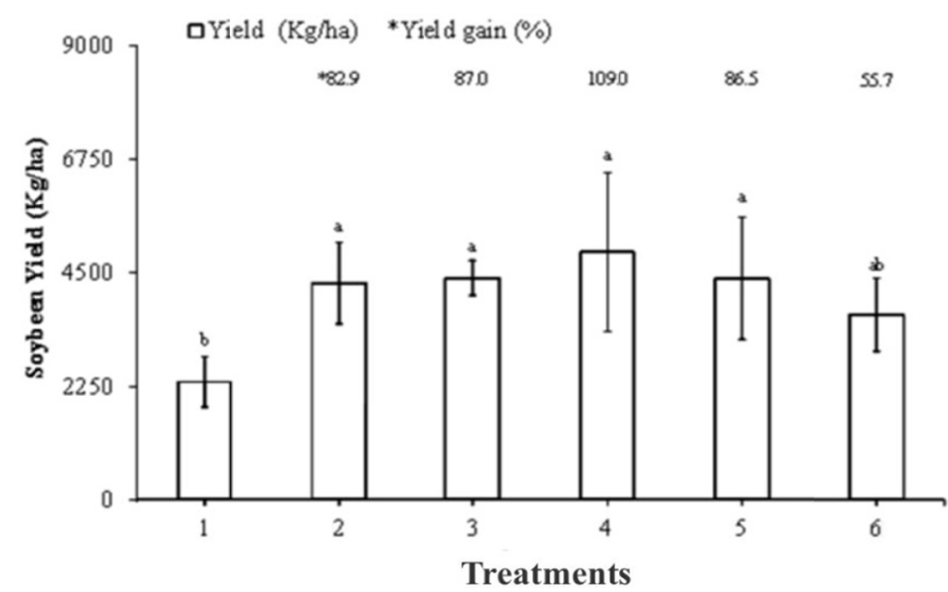

Figure 5. Curative effect of doses Cyproconazole + Azoxystrobin mixtured with the multi-site fungicide Chlorothalonil on the AUDPC (ASR) and leaf fall (Trial 3). The bars represent the standard errors of the means $(n=3)$. Results from one of the two representative experiments are shown.

AUDPC: area under disease progress curve 


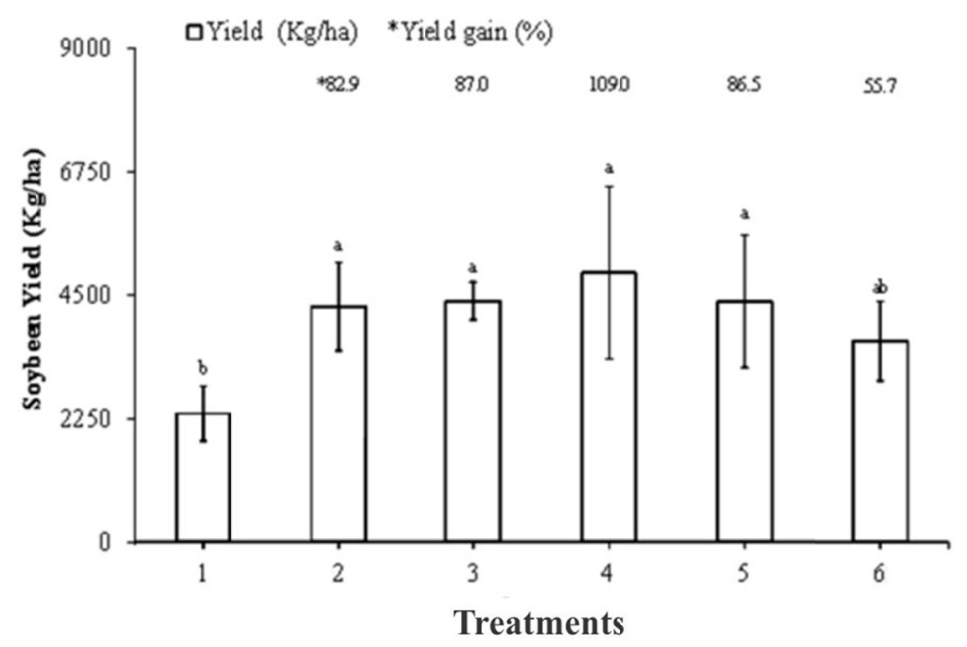

Figure 6. Curative effect of doses of Cyproconazole + Axoxystrobin associated with the multi-site fungicide Chlorothalonil on soybean grain yield (Trial 3). Means followed by the same letter do not differ by the Tukey test $(\mathrm{P} \leq 0.05)$. The bars represent the standard errors of the means. Results from one of the two representative experiments are shown

\section{Discussion}

Three experiments were conducted to know the performance of the triazols + strobilurins (Epoxiconazole + Pyraclostrobin) and Cyproconazole + Azoxystrobin) associated with MSF (Mancozeb, Chlorothalonil, and Metiram) on the control of ASR. The reason to include MSF's in mixture with DMI and QoI fungicides is due to the fact that several researchers reported that the formulations involving triazol + strobilurin have been failed on the control of ASR (Godoy et al., 2015, 2016).

The present study provides a novel information that the association of DMI and QoI with MSF's in different environmental conditions, can improve the efficacy of ASR. Three experiments were conducted in the field (doses of triazoles with stobilurins associated with MSF's (Mancozeb, Chlorothalonil, and Metiram). The purpose of these experiments was to confirm that DMI's and Qol's can be mixtured with the MSF's to improve ASR control and increase soybean yield, preventively and even after the epidemics has reached $2.0 \%$ in the field.

The introduction of MSF in the soybean rust control program may be an important tool for resistance management. They have the potential to preserve the life-time of the site-specific (DMI and QoI) fungicides in soybean crop. The average of ASR control with the application of triazole with strobilurin associated with protectant fungicides was $70.2 \%$. Field trials were sprayed when the disease severity reached $2.0 \%$ on the lower part of the plants. This results shows that any one of the three protectant fungicide can be used in the mixture with Epoxiconazole + Piraclostrobin or Cyproconazole + Azoxystrobin.

Epoxiconazole + Piraclostrobin over $20.5+66.5$ g.a.i./ha and Cyproconazole + Azoxystrobin $50.0+120.0$ g.a.i./ha were phytotoxic to soybean (enrugation of the leaves and lower leaf area) reducing soybean grain yield. Kresoxim-methyl proved to inhibit the biosynthesis of ethylene through reduction of the activity of (ACC)-synthase in tissue of wheat (Grossmann \& Retzlaff, 1997). The available studies in the literature have demonstrated that fungicide application might impairs photosynthesis (Dias, 2012). The physiological effects of Pyraclostrobin was reviewed for Koehle et al. (1997). They reported greening effect, hormonal regulation and assimilation of carbon and nitrogen by the plant when Pyraclostrobin is applied under controlled conditions. This is the first report of strobilurin fungicides formulated with triazol causing phytotoxicity effects on soybean.

Leaf fall in the field experiments followed disease severity. Increasing in the severity of the disease also increased defoliation, except for the higher doses of triazol with strobilurin fungicides. The strobilurin fungicides acts inhibiting the biosynthesis of ethylene through reduction of the activity of (ACC)-synthase (Grossmann \& Retzlaff, 1997). For this reason strobilurin fungicides at higher doses maintained the leaves on the plants and defoliation on these treatments did not follow disease severity.

Grain yield was higher than $100 \%$ when potato was cultivated for two years before soybean compared with the other two areas (crucifers and mayze). The results of the chemical analyses of the leaves were: $\mathrm{N}-5.05 ; \mathrm{P}-0.30$; $\mathrm{K}-1.68 ; \mathrm{Ca}-1.64 ; \mathrm{Mg}-0.25 \mathrm{dag} / \mathrm{kg}$, respectively, which are the optimum level to get a higher soybean grain 
yield. Therefore the chemical control of ASR should take into account also the level of nutrients in the soil (mainly $\mathrm{K}_{2} \mathrm{O}$ ) to achieve higher yields (Fixen et al., 2008; Ballardin et al., 2006).

The efficiency of the ASR control based on the application of triazole and strobirulin is dependent on several factors such as application timing, size of the droplets, type of equipment, uniformity and distribution of the droplets, and environmental conditions. In addition, the deposition of the droplets on the lower part of the plants are more difficult as the growth stage reaches the R2 (blooming stage) and R5 (pods formation) (Zambolim, 2007). Our study showed that the fungicides applied on R1, R2 and R5 stages efficiently promoted ASR control even when the severity of the disease was $2.0 \%$ severity. The severity increased from lower to the upper part of the plant canopy. However, the efficacy of ASR control in the lower, medium and upper part of the canopy, with the application of Epoxiconazole + Pyraclostrobin or Cyproconazole + Azoxistrobin associated with Mancozeb, Chlorothalonil and Metiram significant reduced AUDPC and leaf fall (\%) in the plant canopy. Based on the information above, we can suggest that the application of triazole and strobirulin associated with MSF in the earliest stages of the soybean crop (V9 or R1) could promote a better control especially on the lower part of the plant canopy, the main ASR source of inoculum for the upper part and for the entire field.

Overal the DMI's with QoI's associated with MSF's had an efficiency higher than $68 \%$ and yielded more than $70.2 \%$ over the control. These results showed that it is possible to control ASR even after the disease severity reached $2.0 \%$ at the time of spraying the plants. Protectant MSF's Mancozeb and Chlorothalonil associated with lower doses of Epoxiconazole + Pyraclostrobin $(10.2+33.2$ g.a.i./ha) or Cyproconazole + Azoxystrobin (12.5 + 30.0 g.a.i./ha) increased soybean grain yield at least $45.0 \%$ and the same combination of fungicides at the dose ahead the lower increased $89.5 \%$ and $109.0 \%$, respectively.

Asian soybean rust caused by $P$. pachyrhizi is continuous to be the most challenging disease in Brazil. No single solution will be able to maintain high soybean yields due to the aggressiveness of the pathogen. Disease control relied mainly on systemic fungicides mixtures (DMI + QoI) have been failed, due to the adaptation of the pathogen. The triple mixture of DMI + QoI + SDHI may lead to a strong selection pressure for resistance (Godoy et al., 2016). For these reasons to reduce yield losses, all cultural measures must be take into consideration. In the present work we showed that old multi-site fungicides, e.g. mancozeb, chorothalonil and metiram which have very low resistance risk, when applied in tank mixture with the DMI + QoI increased control efficiency of ASR, soybean yield and reduced leaf fall. These combinations were effectively when they were applied preventively or when the epidemic has reached $2.0 \%$ on the plants.

\section{Conclusion}

Fungicides applied on R1, R2 and R5-3 stages efficiently promoted efficient control of ASR.

The severity of the disease increased from lower to the upper part of the plant canopy.

DMI's with QoI's associated with MSFs had an efficiency higher than $68 \%$ and yielded more than $70.2 \%$ over the control.

It was possible to control ASR even after the disease severity reached $2.0 \%$ at the time of spraying the plants.

Protectant MSFs associated with lower doses of Epoxiconazole + Pyraclostrobin $(10.2+33.2$ g.a.i./ha) or Cyproconazole + Azoxystrobin (12.5 +30.0 g.a.i./ha) increased soybean grain yield at least $45.0 \%$ and the same combination of fungicides at the dose ahead the lower increased $89.5 \%$ and $109.0 \%$, respectively.

The strategy combining DMI + QoI with MSF as proved in the present work, may be recommended as a new strategy for the management of the ASR, at short and long term. Furthermore, multi-site fungicides can promote higher longevity of DMI and QoI molecules, due to the residual effect on soybean leaves.

\section{References}

Andrade, P. J. M., \& Andrade, D. F. A. A. (2006). Controle químico da ferrugem asiática da soja. In L. Zambolim (Ed.), Ferrugem Asiática da Soja (pp. 61-72). Viçosa, Brazil: Universidade Federal de Viçosa.

Balardin, R. S., Dallagnol, L. J., Didoné, H. T., \& Navarini, L. (2006). Influência do fósforo e do potássio na severidade da ferrugem da soja Phakopsora pachyrhizi. Fitopatologia Brasileira, 59(5), 462-467. https://doi.org/10.1590/S0100-41582006000500005

Blum, M. M. C. (2009). Sensitivity of Phakopsora pachyrhizi to Fungicides (PhD thesis, Universidade de Passo Fundo, Passo Fundo, Brazil).

Bromfield K. R. (1984). Soybean rust (Monograph $n^{0} 11$ ). American Phytopathological Society, St. Paul, Minnesota: USA. 
Dias, M. C. (2012). Phytotoxicity: An overview of the physiological responses of plants exposed to fungicides. Journal of Botany. https://doi.org/10.1155/2012/135479

Dorrance, A. E., Draper, M. A., \& Hershman, D. E. (2005). Using Foliar Fungicides to Manage Soybean Rust. Land Grant Universities Cooperating Bulletin: NC 504. North Caroline, USA.

Fehr, W. R., Lawrence, B. K., \& Thompson, T. A. (1981). Critical stages of development for defoliation of soybean. Crop Science, 21(2), 259-262. https://doi.org/10.2135/cropsci1981.0011183X002100020014x

Fixen, P. E., Schneider, R. W., Wright, D. L., Mallarino, A. P., Nelson, K. A., Ebellar, S. A., \& Slaton, N. A. (2008). Implications of asian soybean rust in nutrient management in research update. Better Crop, 92, 26-29.

FRAC (Fungicide Resistance Action Committee). (2015). Global Crop Protection Organization, Brussels. Retrieved from http://www.gcpt.org/frac

Godoy, C. V. (2012). Risk and management of fungicide resistance in the Asian soybean rust fungus Phakopsora pachyrhizi. In T. S. Thind (Ed.), Fungicide resistance in crop protection: Risk and management (pp. 87-95). London: CABI. https://doi.org/10.1079/9781845939052.0087

Godoy, C. V., Koga, L. J., \& Canteri, M. G. (2006). Diagrammatic scale for assessment of soybean rust severity. Fitopatologia Brasileira, 31(1), 63-68. https://doi.org/10.1590/S0100-41582006000100011

Godoy, C. V., Seixas, C. D. S., Soares, R. M., Guimarães, F. C. M., Meyer, M. C., \& Costamilan, L. M. (2016). Asian soybean rust in Brazil: Past, present, and future. Pesquisa Agropecuária Brasileira, 51(5). https://doi.org/10.1590/S0100-204X2016000500002

Godoy, C. V., Utiamada, C. M., Meyer, M. C., Campos, H. D., Forcelini, C. A., Pimenta, C. B., ... Venancio, W. S. (2015). Eficiência de fungicidas para o controle da ferrugem asiática da soja. Phakopsora pachyrhizi, na safra 2014/15: Resultados sumarizados dos ensaios cooperativos. Embrapa Soja, Circular Técnica, 111 (p. 6). Embrapa Soja: Londrina.

Godoy, C. V., Utiamada, C. M., Meyer, M. C., Campos, H. D., Pimenta, C. B., Borges, P., ... Venancio, W. S. (2013). Eficiência de fungicidas para o controle da mancha-alvo, Corynespora cassiicola, na safra 2012/13: Resultados sumarizados dos ensaios cooperativos. Embrapa Soja. Circular Técnica, 100 (p. 6). Londrina: Embrapa Soja.

Grossmann, K., \& Retzlaff, G. (1997). Bioregulatory effects of the fungicidal strobilurin kresoxim-methyl in wheat (Triticum aestivum). Pesticide Science, 5(1), 11-20. https://doi.org/10.1002/(SICI)1096-9063(199705) 50:1\%3C11::AID-PS556\%3E3.0.CO;2-8

Hartman, G. I., Sikora, E. J., \& Rupe, J. C. (2015). Compendium of soybean diseases and pests (5th ed., pp. 56-58). St. Paul: American Phytopathological Society.

Hoagland, D. R., \& Arnon, D. I. (1950). The water-culture method for growing plants without soil (Circular 347). California Agricultural Experiment Station.

Koch, E., Ebrahim, Nesbat, F., \& Hoppe, H. H. (1983). Light and electron microscopic studies on the development of soybean rust (Phakopsora pachyrhizi Syd.) in susceptible soybean leaves. Phytopathol. Z., 106, 302-320.

Köehle, H., Grossmann, K., Retzlaff, G., Saur, R., Akers, A., Gilbert, N., ... Riederer, M. (1997). The yield physiology of kresoximmethyl. The Agronomist, 3, 11-14.

Kranz, J., \& Rotem, J. (1988). Experimental techniques in plant disease epidemiology. Springer-Verlang. https://doi.org/10.1007/978-3-642-95534-1

McGrath, M. T. (2004). What are fungicides: The plant health instructor. Retrieved from http://www.apsnet.org/ education/introplantpath/topics/fungicides/default.htn

Melching, J. S., Dowler, W. M., Koogle, D., \& Royer, M. H. (1989). Effects of duration, frequency, and temperature of leaf wetness periods on soybean rust. Plant Disease, 73(2), 117-122. https://doi.org/ 10.1094/PD-73-0117

Navarini, L., Dallagnol, L. J., Balardin, R. S., Moreira, M. T., Meneghetti, R. C., \& Madalosso, M. G. (2007). Chemical control of soybean rust (Phakopsora pachyrhizi Sidow) in soybean crop. Summa Phytopathologica, 33(2), 182-186. https://doi.org/10.1590/S0100-54052007000200013 
Ogle, H. J., Byth, D. E., \& McLean, R. (1979). Effect of rust (Phakopsora pachyrhizi) on soybean yield and quality in south-eastern Queensland. Australian Journal of Agricultural Research, 30, 883-893. https://doi.org/10.1071/AR9790883

Schmitz, H. K., Medeiros, C. A., Craig, I. R., \& Stammler, G. (2014). Sensitivity of Phakopsora pachyrhizi towards quinone outside-inhibitors and demethylation-inhibitors, and corresponding resistance mechanisms. Pest Management Science West Sussex, 70, 378-388. https://doi.org/10.1002/ps.3562

Shaner, G., \& Finney, R. E. (1977). The effect of nitrogen fertilization on the expression of slow-mildewing resistance in knox wheat. Phytopathology, 67, 1051-1056. https://doi.org/10.1094/Phyto-67-1051

Sinclair, J. B., \& Hartman, G. L. (1999). Soybean Diseases. Compendium of soybean diseases (pp. 3-4). St. Paul, USA: American Phytopathological Society.

Vittal, R., Yang, H., \& Hartman, G. L. (2011). Anastomosis of germ tubes and nuclear migration of nuclei in germ tube networks of the soybean rust pathogen. Phakopsora pachyrhizi. European J. Plant Pathology, 132, 163-167. https://doi.org/10.1007/s10658-011-9872-5

Yang, X. B., Tschanz, A. T., Dowler, W. M., \& Wang, T. C. (1991). Development of yield loss models in relation to reductions of components of soybean infected with Phakopsora pachyrhizi. Phytopathology, 81, 1420-1426. https://doi.org/10.1094/Phyto-81-1420

Yorinori, J. T., \& Lazzarotto, J. J. (2004). Situação atual da ferrugem asiática da soja no Brasil e na América do Sul (Documentos 326). Londrina, Brazil: Embrapa Soja.

Zambolim, L., Venâncio, S. V., \& Oliveira, S. H. F. (2007). Manejo da Resistência de Fungos a Fungicidas (p. 168). Viçosa, Brazil: Universidade Federal de Viçosa.

\section{Copyrights}

Copyright for this article is retained by the author(s), with first publication rights granted to the journal.

This is an open-access article distributed under the terms and conditions of the Creative Commons Attribution license (http://creativecommons.org/licenses/by/4.0/). 